\title{
Assessment of Continuous Gas Resources in the Montney and Doig Formations, Alberta Basin Province, Canada, 2018
}

Using a geology-based assessment methodology, the U.S. Geological Survey estimated undiscovered, technically recoverable mean resources of 47.6 trillion cubic feet of gas and 2.2 billion barrels of natural gas liquids in the Montney and Doig Formations of the Alberta Basin Province in Canada.

\section{Introduction}

The U.S. Geological Survey (USGS) quantitatively assessed the potential for undiscovered, technically recoverable continuous (unconventional) gas resources in the Triassic Montney and Doig Formations of the Alberta Basin Province of Canada (fig. 1). In this study, the upper Montney Formation siltstones were assessed as a tight-gas accumulation (Chalmers and Bustin, 2012), and the Doig Formation phosphatic shales were assessed as a potential shale-gas accumulation (Chalmers and others, 2012).

\section{Total Petroleum Systems and Assessment Units}

The USGS defined an Upper Montney Total Petroleum System (TPS) and a Doig TPS. The upper part of the Montney Formation consists of organic-bearing siltstones that represent distal shelf, slope, and basinal turbidite deposits. These siltstones contain mainly Type II organic matter, have organic carbon contents of as much as 4 weight percent, have hydrogen index values of as much as 450 milligrams of hydrocarbon per gram of organic carbon, are overpressured, and can be as much as 200 meters thick (Chalmers and Bustin, 2012; Schmitz and others, 2014; Crombez and others, 2017). Phosphatic shales of the Doig Formation contain Type II organic matter, have organic carbon contents of as much as 11 weight percent, have hydrogen index values of as much as 485 milligrams of hydrocarbon per gram of organic carbon, are overpressured, and are as much as 180 meters thick (Chalmers and Bustin, 2012). Thermal maturity maps of the Doig Formation show that much of the formation (and underlying part of the upper Montney) is thermally mature for gas generation in the western part of the basin where the upper part of the Montney and Doig are overpressured (Creaney and others, 1994; Ducros and others, 2017). Late Cretaceous through Paleogene foreland burial is generally considered to have thermally matured Montney and Doig source rocks (Chalmers and Bustin, 2012; Ducros and others, 2017).

The geologic model for the Upper Montney TPS is for oil and gas to have been generated in distal organic-bearing siltstones, the oil to have cracked to gas within the overpressured zone, and some of the gas to have been retained within the upper part of the Montney Formation siltstones following migration. The Upper Montney Tight Gas Assessment Unit (AU) was defined to encompass areas of organicrich siltstones within the overpressured gas-generation window. The geologic model for the Doig TPS is for oil and gas to have been generated from condensed, phosphatic Middle Triassic shales from Late Cretaceous-Paleogene burial. Within the overpressured area, oil thermally cracked to gas, which was partially retained within the shales following migration updip into conventional traps. The Doig
Shale Gas AU was defined to encompass areas of organic-rich shale within the overpressured gas-generation window.

Assessment input data are summarized in table 1. Input data from wells within drainage areas in the upper part of the Montney are based mainly on Schmitz and others (2014) and Kwan (2015). Drainage areas (for shales of the Doig Formation), success ratios, and estimated ultimate recoveries of wells are taken from geologic analogs in the United States.

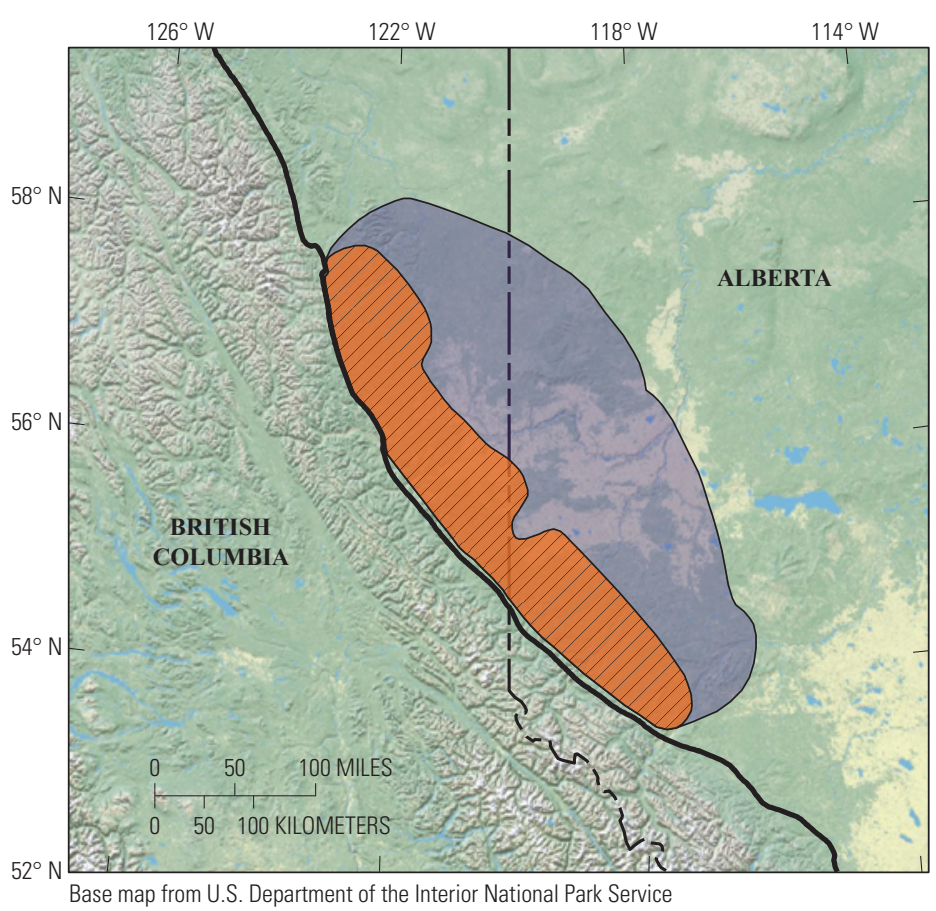

Base map from U.S. Department of the Interior National Park Service

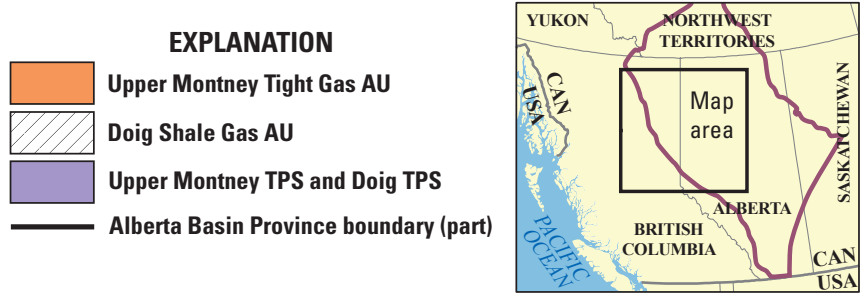

Alberta Basin Province boundary is shown in plum.

Figure 1. Map showing the two continuous assessment units (AUs) in the Montney and Doig Formations of the Alberta Basin Province in Canada. Province boundary is from Klett and others (1997). 


\section{Undiscovered Resources Summary}

The USGS quantitatively assessed continuous gas resources in two assessment units (table 2). For undiscovered, technically recoverable continuous gas resources, the mean totals are 47,616 billion cubic feet of gas (BCFG), or 47.6 trillion cubic feet of gas, with an F95-F5 fractile range from 12,634 to $93,746 \mathrm{BCFG}$ and 2,237 million barrels of (associated) natural gas liquids (MMBNGL), or 2.2 billion barrels of (associated) natural gas liquids, with an F95-F5 fractile range from 579 to 4,552 MMBNGL.

Table 1. Key input data for two continuous assessment units (AUs) in the Montney and Doig Formations of the Alberta Basin Province in Canada.

[AU, assessment unit; \%, percent; EUR, estimated ultimate recovery per well; BCFG, billion cubic feet of gas. Well drainage area, success ratio, and EUR are defined partly using U.S. tight-gas and shale-gas analogs. The average EUR input is the minimum, median, maximum, and calculated mean. Shading indicates not applicable]

\begin{tabular}{|c|c|c|c|c|c|c|c|c|}
\hline \multirow{2}{*}{$\begin{array}{l}\text { Assessment input data- } \\
\text { Continuous AUs }\end{array}$} & \multicolumn{4}{|c|}{ Upper Montney Tight Gas AU } & \multicolumn{4}{|c|}{ Doig Shale Gas AU } \\
\hline & Minimum & Mode & Maximum & $\begin{array}{c}\text { Calculated } \\
\text { mean }\end{array}$ & Minimum & Mode & Maximum & $\begin{array}{l}\text { Calculated } \\
\text { mean }\end{array}$ \\
\hline Potential production area of AU (acres) & 1,000 & $5,650,500$ & $11,301,000$ & $5,650,833$ & 1,000 & $2,000,000$ & $11,301,000$ & $4,434,000$ \\
\hline Average drainage area of wells (acres) & 160 & 200 & 240 & 200 & 80 & 120 & 160 & 120 \\
\hline Untested area $(\%)$ & 85 & 90 & 95 & 90 & 91 & 95 & 99 & 95 \\
\hline Success ratio $(\%)$ & 75 & 85 & 95 & 85 & 10 & 50 & 90 & 50 \\
\hline Average EUR (BCFG) & 0.6 & 1.5 & 2.5 & 1.536 & 0.4 & 0.8 & 1.4 & 0.825 \\
\hline AU probability & 1.0 & & & & 1.0 & & & \\
\hline
\end{tabular}

Table 2. Results for two continuous assessment units (AUs) in the Montney and Doig Formations of the Alberta Basin Province in Canada.

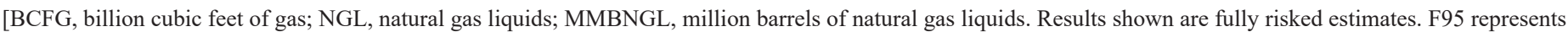

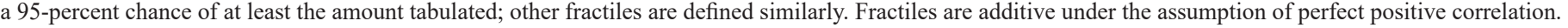
Shading indicates not applicable]

\begin{tabular}{|c|c|c|c|c|c|c|c|c|c|c|}
\hline \multirow{3}{*}{$\begin{array}{l}\text { Total petroleum systems } \\
\text { and assessment units (AUs) }\end{array}$} & \multirow{3}{*}{$\begin{array}{c}\text { AU } \\
\text { probability }\end{array}$} & \multirow{3}{*}{$\begin{array}{c}\text { Accumulation } \\
\text { type }\end{array}$} & \multicolumn{8}{|c|}{ Total undiscovered resources } \\
\hline & & & \multicolumn{4}{|c|}{ Gas (BCFG) } & \multicolumn{4}{|c|}{ NGL (MMBNGL) } \\
\hline & & & F95 & F50 & F5 & Mean & F95 & F50 & F5 & Mean \\
\hline \multicolumn{11}{|c|}{ Upper Montney Total Petroleum System } \\
\hline Upper Montney Tight Gas AU & 1.0 & Gas & 9,969 & 32,192 & 59,143 & 33,072 & 479 & 1,574 & 3,109 & 1,655 \\
\hline \multicolumn{11}{|c|}{ Doig Total Petroleum System } \\
\hline Doig Shale Gas AU & 1.0 & Gas & 2,665 & 12,101 & 34,603 & 14,544 & 100 & 471 & 1,443 & 582 \\
\hline Total undiscovered continuous resources & & & 12,634 & 44,293 & 93,746 & 47,616 & 579 & 2,045 & 4,552 & 2,237 \\
\hline
\end{tabular}

\section{References Cited}

Chalmers, G.R.L., and Bustin, R.M., 2012, Geological evaluation of Halfway-Doig-Montney hybrid gas shale-tight gas reservoir, northeastern British Columbia: Marine and Petroleum Geology, v. 38, no. 1, p. 53-72.

Chalmers, G.R.L., Bustin, R.M., and Bustin, A.A.M., 2012, Geological controls on matrix permeability of the Doig-Montney hybrid shalegas-tight-gas reservoir, northeastern British Columbia (NTS 093P), in Geosciences British Columbia Summary of Activities 2011: Geoscience British Columbia, Report 2012-1, p. 87-96.

Creaney, S., Allan, J., Cole, K.S., Fowler, M.G., Brooks, P.W., Osadetz, K.G., Macqueen, R.W., Snowdon, L.R., and Riediger, C.L., 1994, Petroleum generation and migration in the Western Canada Sedimentary Basin, chap. 31 of Mossop, G., and Shetsen, I., comps., Geological atlas of the Western Canada Sedimentary Basin: Canadian Society of Petroleum Geologists and Alberta Research Council, p. 455-468.

Crombez, V., Baudin, F., Rohais, S., Riquier, L., Euzen, T., Pauthier, S., Ducros, M., Caron, B., and Vaisblat, N., 2017, Basin scale distribution of organic matter in marine fine-grained sedimentary rocks - Insight from sequence stratigraphy and multi-proxies analysis in the Montney and Doig Formations: Marine and Petroleum Geology, v. 83, p. 382-401.

Ducros, M., Sassi, W., Vially, R., Euzen, T., and Crombez, V., 2017, 2-D basin modeling of the Western Canada Sedimentary Basin across the
Montney-Doig system - Implications for hydrocarbon migration pathways and unconventional resources potential, in AbuAli, M.A., Moretti, I., and Norgård Bolås, H.M., eds., Petroleum system analysis - Case studies: American Association of Petroleum Geologists, Memoir 114, p. 117-134.

Klett, T.R., Ahlbrandt, T.S., Schmoker, J.W., and Dolton, G.L., 1997, Ranking of the world's oil and gas provinces by known petroleum volumes: U.S. Geological Survey Open-File Report 97-463, 1 CD-ROM. [Also available at https://pubs.usgs.gov/of/1997/ofr-97-463/97463.html.]

Kwan, M.A., 2015, The evolution of the Montney completion designCompletion-driven well performance compared to Lower 48 plays, in Unconventional Resources Technology Conference, Austin, Texas, July 24-26, 2017, Proceedings: Society of Exploration Geophysicists, American Association of Petroleum Geologists, Society of Petroleum Engineers, URTeC 2691110, 5 p., accessed on July 30, 2018, at https:// www.onepetro.org/conference-paper/URTEC-2691110-MS.

Schmitz, R., Nevokshonoff, G., and Haysom, S., 2014, An integrated approach to development optimization in Seven Generations' Kakwa liquids rich Montney play, in Unconventional Resources Technology Conference, Denver, Colorado, August 25-27, 2014, Proceedings: Society of Exploration Geophysicists, American Association of Petroleum Geologists, Society of Petroleum Engineers, URTeC 1934952, 20 p., accessed on July 30, 2018, at https://library.seg.org/doi/pdf/10.15530/urtec-2014-1934952.

\section{For More Information}

Assessment results are also available at the USGS Energy Resources Program website at https://energy.usgs.gov.

\section{Montney and Doig Formations Assessment Team}

Christopher J. Schenk, Tracey J. Mercier, Marilyn E. Tennyson, Thomas M. Finn, Cheryl A. Woodall, Phuong A. Le, Michael E. Brownfield, Kristen R. Marra, and Heidi M. Leathers-Miller 